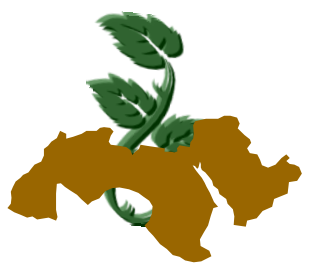

Arab Univ.

J. Agric. Sci., Ain Shams Univ., Cairo, 18(2), 297-306, 2010

\title{
FORTIFICATION OF BISCUITS WITH IRON FROM NATURAL SOURCES
}

\author{
Ayman, E.M. Soliman 1 \\ 1- Food Technology Research Institute, Agricultural Research Center, Giza, Egypt
}

Keywords: Iron, Celery seeds, Cinnamon, Biscuits, Biological evaluation

\begin{abstract}
Iron deficiency anemia is considered one of prevalent patients in developing countries, whereas it is well known that wheat flour is deficient in iron, hence, in this study wheat flour $(72 \%)$ extraction fortified with celery seeds and cinnamon bark meal individually as a natural sources of iron at levels $5,7.5$ and $10 \mathrm{~g} / 100 \mathrm{~g}$ wheat flour and preparation of biscuit samples. Iron content in wheat flour, celery seeds and cinnamon were determined. Biscuit samples were sensory evaluated and baking quality tested. Total iron and available iron were determined in biscuit samples. Biological evaluation for experimental rats designed and histopathological examination was tested for heart organ of rats. The results showed that wheat flour, celery seeds and cinnamon contained from iron 1.98, 57 and $50 \mathrm{mg} / 100 \mathrm{~g}$ respectively. Total iron and available iron increased in biscuits samples by increasing celery seeds and cinnamon additives compared with unfortified biscuits (control). Sensory evaluation of biscuit samples showed slight decrease in color, crunchiness and appearance while odor and taste significantly improved by increasing celery seeds and cinnamon additives compared with control. Baking quality of biscuit samples indicated increasing in weight, while volume, diameter and thickness slightly decreased by increasing celery seeds and cinnamon additives compared with control. Biological evaluation revealed that mean values of hemoglobin, hematocrit, red cell count, mean corpuscular volume, mean corpuscular hemoglobin, mean corpuscular hemoglobin concentration, serum iron and serum ferritin significantly improved after 8 weeks in groups rats fed on biscuits fortified with celery seeds and cinnamon
\end{abstract}

compared with control. Histopathological overhaul declared amelioration in organ heart for groups rats fed on biscuits fortified with celery seeds and cinnamon compared with anemic control.

\section{INTRODUCTION}

Iron is an essential element has several vital function in the body. It serves as a carrier of oxygen to the tissues, the lungs by red blood cell hemoglobin as a transport medium for electrons within cell and as an integrated part of important enzymes in various tissue. Disturbance of iron metabolism are part of the metabolic syndrome which clusters insulin resistance, hyperinsulinemia, hyperglycemia, hypertension and obesity (Sandrine et al 2008).

Iron is an important mineral for our body, primarily used in the formation of hemoglobin which in turn takes oxygen to different parts of body with the help of feritin and transferrin proteins. Thus, iron carries oxygen from the lungs through red blood cells and distributes it to the rest of the body's muscles and tissue's (Ekhard et al 2009).

Iron deficiency is common in developing countries, where the diet is largely cereal-based and contains little animal protein and it will take a long time for dietary changes to result in improvements in iron status. One way to ensure the adequate iron nutrition of a population is to fortify commonly consumed foods with iron and provide the foods in relatively predictable amounts. Food fortification and supplementation are generally considered the best approaches for combating iron deficiency in a population (Laura and Beard 2009).

Iron deficiency can be defined as occurring when the body's iron stores become depleted and a restricted supply of iron to various tissues becomes apparent. The clear consequences of iron depletion are a reduction in oxygen transport ca- 
pacity and a reduction in oxidative capacity at the cellular level of functioning. The process by which iron stores are depleted may occur rapidly or very slowly and depends on the balance between iron intake and iron requirements (Barbara et al 2009).

Iron deficiency is the most common single nutrient deficiency disease in the world and is a major concern for $\approx 15 \%$ of the world's population. The commonly used definition for anemia, regardless of its cause, is a low hemoglobin concentration. If iron deficiency is an underlying etiology, then by definition an individual must have depleted iron stores, low ferritin in plasma or decreased stainable iron in bone marrow and inadequate delivery of iron to tissues as characterized by a low transferrin saturation, a high erythrocyte protoporphyrin concentration and an elevated transferring receptor concentration (Zhenyu et al 2008).

Celery seeds or one of its extractives used in the flavoring of beverages, confections, chewing gums, ice creams, pizza loaf and baked good. Ground cinnamon oil and/or the oleoresin of cinnamon is used commercially in the manufacture of confection, ice cream, beverages, chewing gum, cakes, cookies, pies and other baked good. Moreover, celery seeds and cinnamon rich content in iron (Farrell, 1999).

The intention of this study was carried out to produce biscuits fortified with celery seeds and cinnamon as a natural sources of iron and studying chemical composition and iron content in raw materials, moreover, investigation sensory evaluation and baking quality of biscuits samples, furthermore, evaluation iron blood picture for experimental rats fed on biscuits.

\section{MATERIALS AND METHODS}

\section{Materials}

Celery seeds (Apium graveolens L.) and cinnamon (cinnamomum zeylanicum Nees) were obtained in 2009 from Medicinal and Aromatic Plants Research Department, Agriculture Research Center, Giza, Egypt.

Wheat flour (72\% extraction) was obtained in 2009 from North Cairo Mills Company, El-Hoda Mill, Shobra El-Kheima, Egypt.

Vitamins mixture were obtained from Sigma Chemical Company, USA.

Minerals mixture were obtained from ADWIC Company Egypt.
Kits were purchased from Randox Laboratories LTD. USA. (70 Dorman St., Suite 3 A San Francesco, CA 94124).

Sixty-four male albino rats of wistar strain average weight $85 \pm 5 \mathrm{~g}$ were obtained from the Laboratory Animal Colony, Vaccine and Immunity Organization, Cairo, Egypt.

\section{Methods}

\section{Preparation of celery seeds powder}

Celery seeds were milled via laboratory mill (Retsch GmbH5657HAAN) to get the fine celery seeds powder.

\section{Biscuits preparation}

Biscuits samples were prepared according to the method of Wade (1988). Biscuits formula was consists of $100 \mathrm{gm}$ wheat flour $(72 \%$ extraction rate) control or fortification with $5,7.5$ and $10 \mathrm{gm}$ celery seeds and cinnamon, $40 \mathrm{gm}$ sugar, $12 \mathrm{gm}$ butter milk, $18 \mathrm{gm}$ water, $20 \mathrm{gm}$ milk, $3 \mathrm{gm}$ baking powder, $25 \mathrm{gm}$ egg and $1 \mathrm{gm}$ vanilla. Butter, sugar and vanillia were mixed in a dough mixer using the flat beater for 1 minute, then scraped down and continued to mix for 3 minutes at high speed. When flour and baking powder were added to the mixture and mixed at low speed then it was sheeted to $15 \mathrm{~mm}$ thickness. Circle pieces cut of dough were formed by using of templates with an outer diameter of $45 \mathrm{~mm}$. The biscuits were baked at $180^{\circ} \mathrm{C}$ for 12 minutes. Biscuit samples were cooled and packed in bags made from low density polyethylene (Density $0.915 \mathrm{~g} / \mathrm{cm}^{3}$ ).

\section{Sensory evaluation}

The color, taste, odor, appearance and crunchiness of the biscuit samples were evaluated according to method of Wade (1988).

\section{Baking quality}

The baking quality of biscuits test included weight, volume, specific volume, diameter, thickness and expansion factor were determined according to methods of AACC (2002).

\section{Chemical analysis}

Moisture, protein, fat, fiber, ash, total iron, available (soluble) iron, phytate phosphorus and tannins were determined according to the methods of AOAC (2005). 


\section{Biological evaluation}

Sixty-four male rats were housed individually in stainless steel cages with wire mesh floor. Distilled water and diets were offered ad libitum. Baseline mean of hemoglobin was found to about 13-14 $\mathrm{g} / \mathrm{dl}$. After 3 days adaptation period rats were divided randomly into eight groups ( $n=8$ rats) as follow: Group 1 fed on basal diet consist of $10 \%$ casein, $10 \%$ corn oil, $4 \%$ salts mixture, $1 \%$ vitamins mixture, $5 \%$ cellulose and $70 \%$ starch according to AIN (1977) and considered as normal control. Fifty six rats were fed on basal diet free from iron for four weeks until the hemoglobin level decreased to about $9-10 \mathrm{~g} / \mathrm{dl}$ (anemia state). Group 2 fed on basal diet free from iron until end of experimental and considered anemic control. Group No. 3, 4 and 5 fed on biscuits fortified with 5, 7.5 and $10 \mathrm{~g} / 100 \mathrm{gm}$ celery seeds respectively. Group No. 6, 7 and 8 fed on biscuits fortified with 5, 7.5 and $10 \mathrm{~g} / 100 \mathrm{gm}$ cinnamon respectively. After 8 weeks blood was withdrawn from the orbital puncture by a heparinized capillary tube containing heparin as a blood anticoagulant then, blood was centrifuged at 3000 r.p.m (10 min) to obtain the serum which was stored at $\left(-20^{\circ} \mathrm{C}\right)$ for biochemical analysis. On the finial day of the experiment the rat were fasted overnight and anesthetized by using overexposure to diethyl ether then rats were sacrificed by decapitation.

\section{Biochemical analysis}

Hemoglobin $(\mathrm{Hb})$ :- To $20 \mu \mathrm{l}$ of the whole blood sample, $5 \mathrm{ml}$ of cyanme thenoglobine reagent (Egle diagnostics) was added. After standing $3 \mathrm{~min}$ at room temperature, the formed colour was measured at $540 \mathrm{~nm}$ against reagent blank (cyanme thenoglobine) using Spicol Colorimeter. $\mathrm{Hb}$ concentration (grams per deciliter) was calculated according to Wintrobe (1965) using the following equation:

\section{$H b(g / d l)=$ optical density of sample/optical density of standard $\times 36.77$}

Hematocrit $(\mathrm{Ht})$ : Hematocrit determination was done according to Dacie and Lewis (1984) using the micro-method. Heparinized microhaematocrit tubes were used, filled with capillary blood, sealed and centrifuged at $3000 \mathrm{rpm}$ for $5 \mathrm{~min}$.

Red blood cell count (RBCs):- Red blood cell were counted on hemocytometer using a light microscope at $40 \mathrm{X}$ magnification after diluting the blood samples 200 times with a physiological saline solution ( $0.9 \%$ sodium chloride solution) before counting (Heplar, 1966).

Red corpuscular values: Absolute red cell values were calculated according to Dacie and Lewis (1984) as follows:

- Mean corpuscular volume (MCV) = [hematocrit (\%) $\times 10] \div$ RBCs (millions $/ \mathrm{mm}^{3}$ ) as femtoliter (fl). - Mean corpuscular hemoglobin $(\mathrm{MCH})=[\mathrm{Hb}$ $(\mathrm{g} / \mathrm{dl}) \times 10] \div \mathrm{RBCs}$ (millions $/ \mathrm{mm}^{3}$ ) as pico gram (pg).

- Mean corpuscular hemoglobin concentration $(\mathrm{MCHC}) \%=[\mathrm{Hb}(\mathrm{g} / \mathrm{dl}) \div$ hematocrit $] \times 100$.

Serum iron (SI) was measured according to method of Dacie and Lewis (1984).

Serum ferritin (SF) was assessed by enzyme linked immunosorbent assay according to method of Flowers et al (1986).

\section{Histopathological examination}

The heart was kept in $10 \%$ formalin vatile embedded in paraffin wax, then heart sectioned at the thickness of $6 \mu$ and stained in hoematoxyli and eosin mixture according to Yoon et al (2001). Tissue section heart examined using ordinary microscope at 200 magnification.

\section{Statistical analysis}

The obtained results were analyzed using Statistical Analysis System SAS (2001).

\section{RESULTS AND DISCUSSION}

\section{Chemical composition of raw materials}

An adequate knowledge of the chemical composition of food is vital to the health, well-being and safety of the consumer.

Raw materials (wheat flour, celery seeds cinnamon) were chemically analyzed and the results were illustrated in Table (1). The results revealed that the moisture, protein, fat, fiber, ash and carbohydrates contents in wheat flour $(72 \%)$ extraction were 10.95, 10.38, 1.10, 0.65, 0.50 and $87.37 \%$ respectively. From the same table it is obvious that the moisture, protein, fat, fiber, ash and carbohydrates contents in celery seeds were $8.45,17.98,2.91,3.22,3.15$ and $72.74 \%$ respectively. It can be seen from the same table that the moisture, protein, fat, fiber, ash and carbohydrates contents in cinnamon were 9.83, 4.12, 2.84, 4.81, 2.90 and $85.33 \%$ respectively. 
Table 1. Chemical composition (\%) of raw materials (on dry weight basis) ${ }^{\star}$

\begin{tabular}{|l|c|c|c|c|c|c|}
\hline \multicolumn{1}{|c|}{ Samples } & Moisture & Protein & Fat & Fiber & Ash & Carbohydrates $^{* *}$ \\
\hline Wheat flour (72\%) & $10.95 \pm 0.81 \mathrm{a}$ & $10.38 \pm 0.73 \mathrm{~b}$ & $1.10 \pm 0.28 \mathrm{~b}$ & $0.65 \pm 0.19 \mathrm{c}$ & $0.50 \pm 0.11 \mathrm{~b}$ & $87.37 \pm 1.23 \mathrm{a}$ \\
Celery seeds & $8.45 \pm 0.96 \mathrm{c}$ & $17.98 \pm 0.65 \mathrm{a}$ & $2.91 \pm 0.42 \mathrm{a}$ & $3.22 \pm 0.23 \mathrm{~b}$ & $3.15 \pm 0.22 \mathrm{a}$ & $72.74 \pm 1.58 \mathrm{c}$ \\
Cinnamon & $9.83 \pm 0.91 \mathrm{~b}$ & $4.12 \pm 0.31 \mathrm{c}$ & $2.84 \pm 0.25 \mathrm{a}$ & $4.81 \pm 0.37 \mathrm{a}$ & $2.90 \pm 0.17 \mathrm{a}$ & $85.33 \pm 1.17 \mathrm{~b}$ \\
\hline L.S.D (0.05) & 0.21 & 0.10 & 0.71 & 0.83 & 0.51 & 0.95 \\
\hline
\end{tabular}

* Values are mean \pm standard error

* Values in the same column with different superscript letters $(a, b, \ldots)$ are significantly difference.

** Calculated by difference

\section{Iron and phytate phosphorus content of raw materials}

With respect to iron content of raw materials the results in Table (2) indicated that wheat flour, celery seeds and cinnamon contained from iron $1.98,57$ and $50 \mathrm{mg} / 100 \mathrm{~g}$ respectively. From the same table, the data evinced that wheat flour contained from phytate phosphorus $21 \mathrm{mg} / 100 \mathrm{~g}$ while, celery seeds and cinnamon did not contained phytate phosphorus or tannin. These results are in agreement with those mentioned by Leif and Lena (2000). Meanwhile, Janet et al (2009) reported that several factors affect on iron absorption. For example, tannins and phylate phosphorus in food reduce iron absorption, while ascorbic acid increases it.

\section{Sensory evaluation}

Sensory evaluation is considered as an important indicator of potential consumer preferences. Inspite of its short comings it will remain one of the most reliable quality assessment technique for food and food products in general and for bread and bakery products in particular.

With respect to sensory evaluation of biscuit samples the present data in Table (3) appeared that color, crunchiness and appearance slightly decreased in biscuit samples fortified with celery seeds and cinnamon at levels 5, 7.5 and $10 \mathrm{gm}$ compared with biscuits unfortified (control). On the contrary, odor and taste significantly improved in biscuit samples fortified with celery seeds and cinnamon at levels 5, 7.5 and $10 \mathrm{gm}$ compared with biscuits unfortified (control). This significance increasing in odor and taste may be attributed to the volatile oil finding in celery seeds and cinnamon which it is known that enhance the odor and taste. Generally, aromatic plants and spices may improve, enhance or attribute a certain flavor to bakery products. The roasted aroma is one of the attractive flavors. It is the characteristics of all high temperature processing foods including bakery products. Pyrazine compounds are responsible for this roasted aroma (Bassiouny et al 1990).

\section{Baking quality}

Biscuits is important bakery items and used all day and considered is one of the major delicate and delicious foods and is not restricted to any particular of the day. It has very long shelf life, as they are not prone to destruction by fingers etc.

Concerning baking quality of biscuit samples, the obtained data in Table (4) elucidated that weight increased in biscuit samples fortified with celery seeds and cinnamon at levels 5, 7.5 and 10 gm compared with biscuits unfortified (control). This increasing in weight might be attributed to the higher fiber content in celery seeds and cinnamon causing higher water holding capacity (Shogren et al 1981). In contrast, volume, specific volume, diameter, thickness and expansion factor slightly decreased by increasing celery seeds and cinnamon levels compared with biscuits unfortified (control). These decreasing may be imputed to increase water holding capacity of the fiber component may have contributed to the higher batter 
Table 2. Iron, phytate phosphorus and tannins content $(\mathrm{mg} / 100 \mathrm{~g})$ of raw materials (on dry weight basis)

\begin{tabular}{|c|c|c|c|}
\hline Samples & Iron & Phytate phosphorus & Tannins \\
\hline Wheat flour (72\%) & 1.98 & 21 & N.D \\
Celery seeds & 57 & N.D* & N.D \\
Cinnamon & 50 & N.D & N.D \\
\hline
\end{tabular}

${ }^{*} \mathrm{~N} . \mathrm{D}=$ not detected

Table 3. Sensory evaluation of biscuit samples*

\begin{tabular}{|l|c|c|c|c|c|}
\hline \multicolumn{1}{|c|}{ Samples } & \multicolumn{1}{|c|}{$\begin{array}{c}\text { Color } \\
\mathbf{( 2 0 )}\end{array}$} & $\begin{array}{c}\text { Crunchiness } \\
\mathbf{( 2 0 )}\end{array}$ & $\begin{array}{c}\text { Odor } \\
\mathbf{( 2 0 )}\end{array}$ & $\begin{array}{c}\text { Taste } \\
\mathbf{( 2 0 )}\end{array}$ & $\begin{array}{c}\text { Appearance } \\
\mathbf{( 2 0 )}\end{array}$ \\
\hline Biscuits unfortified (control) & $19.88 \pm 0.79 \mathrm{a}$ & $19.53 \pm 0.56 \mathrm{a}$ & $18.35 \pm 0.51 \mathrm{~b}$ & $18.20 \pm 0.74 \mathrm{~b}$ & $19.60 \pm 0.45 \mathrm{a}$ \\
Biscuits (5 gm celery seeds) & $19.75 \pm 0.82 \mathrm{a}$ & $19.50 \pm 0.61 \mathrm{a}$ & $18.38 \pm 0.42 \mathrm{~b}$ & $18.27 \pm 0.65 \mathrm{~b}$ & $19.55 \pm 0.61 \mathrm{a}$ \\
Biscuits (7.5gm celery seeds) & $19.63 \pm 0.53 \mathrm{a}$ & $19.47 \pm 0.87 \mathrm{a}$ & $18.42 \pm 0.65 \mathrm{~b}$ & $18.45 \pm 0.51 \mathrm{~b}$ & $19.12 \pm 0.36 \mathrm{a}$ \\
Biscuits (10 gm celery seeds) & $18.20 \pm 0.62 \mathrm{~b}$ & $19.41 \pm 0.88 \mathrm{a}$ & $19.50 \pm 0.48 \mathrm{a}$ & $19.61 \pm 0.68 \mathrm{a}$ & $18.00 \pm 0.47 \mathrm{~b}$ \\
Biscuits (5 gm cinnamon) & $19.71 \pm 0.91 \mathrm{a}$ & $19.51 \pm 0.69 \mathrm{a}$ & $18.40 \pm 0.39 \mathrm{~b}$ & $18.33 \pm 0.72 \mathrm{~b}$ & $19.50 \pm 0.30 \mathrm{a}$ \\
Biscuits (7.5 gm cinnamon) & $19.65 \pm 0.95 \mathrm{a}$ & $19.44 \pm 0.97 \mathrm{a}$ & $19.67 \pm 0.40 \mathrm{a}$ & $19.60 \pm 0.76 \mathrm{a}$ & $19.47 \pm 0.45 \mathrm{a}$ \\
Biscuits (10 gm cinnamon) & $18.40 \pm 0.76 \mathrm{~b}$ & $19.38 \pm 0.75 \mathrm{a}$ & $19.86 \pm 0.33 \mathrm{a}$ & $19.78 \pm 0.51 \mathrm{a}$ & $18.11 \pm 0.56 \mathrm{~b}$ \\
\hline L.S.D. (0.05) & 0.56 & 0.42 & 0.63 & 0.29 & 0.47 \\
\hline
\end{tabular}

* Values are mean \pm standard error

* Values in the same column with different superscript letters $(a, b, \ldots)$ are significantly difference.

Table 4. Baking quality of biscuit samples ${ }^{*}$

\begin{tabular}{|c|c|c|c|c|c|c|}
\hline Samples & $\begin{array}{l}\text { Weight } \\
\text { (g) }\end{array}$ & $\begin{array}{l}\text { Volume } \\
\text { (cc) }\end{array}$ & $\begin{array}{c}\text { Specific } \\
\text { volume } \\
(v / w) \\
\end{array}$ & $\begin{array}{l}\text { Diameter } \\
\text { (cm) }\end{array}$ & $\begin{array}{c}\text { Thickness } \\
\text { (cm) }\end{array}$ & $\begin{array}{c}\text { Expansion } \\
\text { factor } \\
\text { (Di/Th) }\end{array}$ \\
\hline Biscuits unfortified (control) & $22.51 \pm 0.11 b$ & $37.54 \pm 0.23 a$ & $1.66 \pm 0.16 a$ & $4.58 \pm 0.18 a$ & $1.51 \pm 0.06 a$ & $3.03 \pm 0.09 a$ \\
\hline Biscuits (5 gm celery seeds) & $22.94 \pm 0.16 b$ & $36.97 \pm 0.20 a$ & $1.61 \pm 0.25 a$ & $3.97 \pm 0.12 a$ & $1.37 \pm 0.04 a$ & $2.89 \pm 0.09 a$ \\
\hline Biscuits (10 gm celery seeds) & $23.88 \pm 0.18 a$ & $36.41 \pm 0.26 b$ & $1.52 \pm 0.18 b$ & $3.55 \pm 0.21 b$ & $1.25 \pm 0.08 b$ & $2.84 \pm 0.11 b$ \\
\hline Biscuits (5 gm cinnamon) & $22.89 \pm 0.11 b$ & $36.74 \pm 0.23 a$ & $1.60 \pm 0.34 a$ & $3.80 \pm 0.26 a$ & $1.32 \pm 0.04 a$ & $2.87 \pm 0.06 a$ \\
\hline Biscuits (7.5 gm cinnamon) & $22.93 \pm 0.08 a b$ & $36.48 \pm 0.19 a$ & $1.59 \pm 0.27 a$ & $3.56 \pm 0.11 \mathrm{a}$ & $1.26 \pm 0.09 a$ & $2.82 \pm 0.11 \mathrm{a}$ \\
\hline
\end{tabular}

* Values are mean \pm standard error

* Values in the same column with different superscript letters $(a, b, \ldots)$ are significantly difference. 
viscosity and if these components competed with the starch for water, incomplete gelatinization of the starch could have resulted in reduction of biscuits volume (Shogren et al 1981).

Total, available and availability iron of biscuit samples (In-vitro)

With regard to total, available and availability iron of biscuits samples, the given results in Table (5) demonstrated that total, available and availability iron increased in biscuits samples fortified with celery seeds and cinnamon by increasing celery seeds and cinnamon additives compared with biscuits unfortified (control). Schricker and Miller (1982) mentioned that the baking process had little effect on the relative availability.

\section{Biological evaluation (In-vivo)}

In relation to blood picture in groups of rats, the data in Table (6) evinced that mean values of hemoglobin $(\mathrm{Hb})$, hematocrit $(\mathrm{Ht})$, red blood cell (RBC), mean cropuscular volume (MCV), mean cropuscular hemoglobin $(\mathrm{MCH})$ mean cropuscular hemoglobin concentration (MCHC), serum iron (SI) and serum ferritin (SF) significantly improved after 8 weeks in groups rats fed on biscuits fortified with celery seeds and cinnamon at levels 5, 7.5 and 10 gm compared with anemic control group fed on biscuits unfortified. These results are in agreement with those reported by John and Brian (2002) who reported that iron deficiency anemia cause low hemoglobin serum iron (SI), also iron deficiency lead to decrease in mean corpuscular hemoglobin $(\mathrm{MCH})$ and size of red cell. Mark et al (2009) noted that daily iron intake depends on the composition of food consumed and the quantity of iron therein. Several inhibitors and a small number of enhancers of iron absorption are now known to exist. Iron absorption increases in individuals who have depleted iron status and this internal regulator of absorption may be more important than any particular constituents of the food supply. Therewithal Melissa et al (2009) appeared that basal obligatory losses in humans are $\approx 1 \mathrm{mg} \mathrm{Fe} / \mathrm{d}$ and must be replaced by an equivalent amount of iron derived from the diet. The typical Western diet provides an average of $6 \mathrm{mg}$ of heme and nonheme iron per $4120 \mathrm{~kJ}$ of energy intake. The bioavailability of iron is both a function of its chemical form and the presence of food items that promote or inhibit its absorption. Ascorbic acid and meat are known as the most powerful of these enhancers of nonheme iron absorption, whereas the list of inhibitors is much longer. In contrast to heme iron absorption, many factors affect nonheme iron absorption and include bran, hemicellulose, cellulose, pectin, phytic acid which is found in wheat and soy products and polyphenolic compounds. Besides Janet et al (2009) mentioned that one of the causes of nutritional anemia is that the amount of iron absorbed is insufficient to meet the body's requirements. This insufficiency may be due to both inadequate iron intake from food and to low bioavailability. Most of the iron in the body is present in the red blood cells, mainly as a component of hemoglobin. Much of the rest is present in myoglobin, a compound occurring mainly in muscles and as storage iron or ferritin, mainly in the liver, spleen and bone marrow. Additional tiny quantities are found binding protein in the blood plasma and in respiratory enzymes. In normal circumstances, only about $1 \mathrm{mg}$ of iron is lost from the body daily by excretion into the intestines, in urine, in sweat or through loss of hair or surface epithelial cells.

\section{Histopathological examination}

Table (7) and Figures (1), (2), (3) \& (4) illustrated histopathological overhaul of organ heart for groups rats fed on biscuits fortified with $10 \mathrm{gm} /$ 100 gm celery seeds (group No. 5 and Fig. 3) and cinnamon (group No. 8 and Fig. 4) compared with normal control (Fig. 1) and anemic control (Fig. 2) groups of organ heart. Briefly, can be said that histopathological overhaul declared amelioration in organ heart for groups rats fed on biscuits fortified with celery seeds and cinnamon compared with anemic control.

In conclusion, from aforementioned results it is evident that fortification of food with iron especially from natural sources is considered the best way for overcome iron deficiency. Natural sources of iron can be used safely because it better than synthetics sources of iron. Therewithal, fortified food can be considered healthy food or functional food which had healthy benefits. 
Table 5. Values of total, available and availability iron of biscuit samples

\begin{tabular}{|l|c|c|c|}
\hline \multicolumn{1}{|c|}{ Samples } & $\begin{array}{c}\text { Total iron } \\
(\mathbf{m g} / \mathbf{1 0 0} \mathbf{~ g})\end{array}$ & $\begin{array}{c}\text { Available iron } \\
(\mathbf{m g} / \mathbf{1 0 0} \mathbf{~ g})\end{array}$ & $\begin{array}{c}\text { Availability iron } \\
\mathbf{( \% )}\end{array}$ \\
\hline Biscuits unfortified (control) & 1.92 & 0.83 & 43.22 \\
Biscuits (5 gm celery seeds) & 3.40 & 1.97 & 57.94 \\
Biscuits (7.5gm celery seeds) & 5.85 & 3.86 & 65.98 \\
Biscuits (10 gm celery seeds) & 8.17 & 6.42 & 78.58 \\
Biscuits (5 gm cinnamon) & 3.11 & 1.63 & 52.41 \\
Biscuits (7.5 gm cinnamon) & 4.23 & 2.60 & 61.46 \\
Biscuits (10 gm cinnamon) & 7.00 & 5.30 & 75.71 \\
\hline
\end{tabular}

Table 6. Blood picture in groups of rats*

\begin{tabular}{|c|c|c|c|c|c|c|c|c|}
\hline & $\begin{array}{l}\mathrm{Hb} \\
(\mathrm{g} / \mathrm{dl})\end{array}$ & $\begin{array}{l}\mathrm{Ht} \\
(\%)\end{array}$ & $\begin{array}{c}\text { RBC } \\
\text { (millions } / \mathrm{mm}^{3} \text { ) }\end{array}$ & $\begin{array}{l}\text { MCV } \\
\text { (fl) }\end{array}$ & $\begin{array}{r}\mathrm{MCH} \\
(\mathrm{Pg})\end{array}$ & $\begin{array}{c}\text { MCHC } \\
(\%)\end{array}$ & $\begin{array}{c}\text { SI } \\
(\mu \mathrm{mol} / \mathrm{l})\end{array}$ & $\begin{array}{l}\text { SF } \\
(\mu \mathrm{g} / \mathrm{l})\end{array}$ \\
\hline \multirow{2}{*}{$\begin{array}{l}\text { Normal control } \\
\text { (Group. No 1) }\end{array}$} & 13.65 & 42.37 & 4.67 & 90.72 & 29.22 & 32.21 & 11.68 & 13.72 \\
\hline & $\pm 0.73 a$ & $\pm 0.60 \mathrm{a}$ & $\pm 0.25 a$ & $\pm 1.15 a$ & $\pm 0.31 \mathrm{a}$ & $\pm 0.20 \mathrm{a}$ & $\pm 0.17 a$ & $\pm 0.23 a$ \\
\hline \multirow{2}{*}{$\begin{array}{c}\text { Anemic control } \\
\text { (Group. No.2) }\end{array}$} & 9.18 & 38.11 & 4.30 & 88.62 & 21.34 & 24.08 & 9.53 & 9.91 \\
\hline & $\pm 0.52 d$ & $\pm 1.81 d$ & $\pm 0.21 b$ & $\pm 1.11 \mathrm{c}$ & $\pm 0.35 d$ & $\pm 0.26 d$ & $\pm 0.21 b$ & $\pm 0.25 d$ \\
\hline \multirow{2}{*}{ Group No. $3^{* *}$} & 10.87 & 39.25 & 4.42 & 88.80 & 24.59 & 27.69 & 11.17 & 10.84 \\
\hline & $\pm 0.63 c$ & $\pm 2.70 \mathrm{c}$ & $\pm 0.23 a$ & $\pm 1.16 \mathrm{c}$ & $\pm 0.30 \mathrm{c}$ & $\pm 0.21 \mathrm{c}$ & $\pm 0.12 \mathrm{a}$ & $\pm 0.16 \mathrm{c}$ \\
\hline \multirow{2}{*}{ Group No. $4^{* *}$} & 12.59 & 41.19 & 4.60 & 89.54 & 27.36 & 30.56 & 11.29 & 12.17 \\
\hline & $\pm 0.70 \mathrm{~b}$ & $\pm 1.18 b$ & $\pm 0.27 a$ & $\pm 1.22 \mathrm{~b}$ & $\pm 0.38 \mathrm{~b}$ & $\pm 0.19 \mathrm{~b}$ & $\pm 0.15 a$ & $\pm 0.20 \mathrm{~b}$ \\
\hline \multirow{2}{*}{ Group No. $5^{\star *}$} & 13.48 & 41.90 & 4.65 & 90.10 & 28.98 & 32.17 & 11.61 & 13.23 \\
\hline & $\pm 0.41 \mathrm{a}$ & $\pm 1.87 \mathrm{a}$ & $\pm 0.20 \mathrm{a}$ & $\pm 1.37 \mathrm{a}$ & $\pm 0.28 \mathrm{a}$ & $\pm 0.23 \mathrm{a}$ & $\pm 0.23 a$ & $\pm 0.21 \mathrm{a}$ \\
\hline \multirow{2}{*}{ Group No. $6^{* * *}$} & 10.26 & 39.10 & 4.41 & 88.66 & 23.26 & 26.24 & 10.75 & 10.73 \\
\hline & $\pm 0.67 \mathrm{c}$ & $\pm 2.23 \mathrm{c}$ & $\pm 0.16 \mathrm{a}$ & $\pm 1.18 \mathrm{c}$ & $\pm 0.36 \mathrm{c}$ & $\pm 0.15 c$ & $\pm 0.10 \mathrm{ab}$ & $\pm 0.13 \mathrm{c}$ \\
\hline \multirow{2}{*}{ Group No. $7^{* * *}$} & 11.43 & 41.11 & 4.60 & 89.36 & 24.84 & 27.80 & 11.23 & 11.98 \\
\hline & $\pm 0.82 \mathrm{bc}$ & $\pm 0.75 b$ & $\pm 0.13 a$ & $\pm 1.23 \mathrm{~b}$ & $\pm 0.39 \mathrm{c}$ & $\pm 0.26 \mathrm{c}$ & $\pm 0.19 a$ & $\pm 0.22 \mathrm{~b}$ \\
\hline \multirow{2}{*}{ Group No. $8^{* * *}$} & 12.92 & 41.35 & 4.62 & 89.50 & 27.96 & 31.24 & 11.52 & 12.86 \\
\hline & $\pm 0.35 \mathrm{a}$ & $\pm 0.91 \mathrm{a}$ & $\pm 0.19 \mathrm{a}$ & $\pm 1.32 \mathrm{a}$ & $\pm 0.28 \mathrm{a}$ & $\pm 0.28 \mathrm{a}$ & $\pm 0.24 \mathrm{a}$ & $\pm 0.11 \mathrm{a}$ \\
\hline L.S.D (0.05) & 0.40 & 0.85 & 0.15 & 0.67 & 0.22 & 0.23 & 0.20 & 0.17 \\
\hline
\end{tabular}

Table 7. Lesion score for heart organ of groups rats

\begin{tabular}{|l|c|c|c|c|}
\hline Lesion & Normal control (G. No. 1) & Anemic control (G. No. 2) & G. No. 5 & G. No. 8 \\
\hline Congestion & - & ++ & - & - \\
Hemorrhage & - & +++ & - & + \\
Inflammation & - & +++ & + & + \\
\hline
\end{tabular}

- = Absence of lesion $\quad+=$ Presence of lesion by mild degree

$++=$ Presence of lesion by moderate degree $\quad+++=$ Presence of lesion by considerable degree $++++=$ Presence of lesion by severe degree 


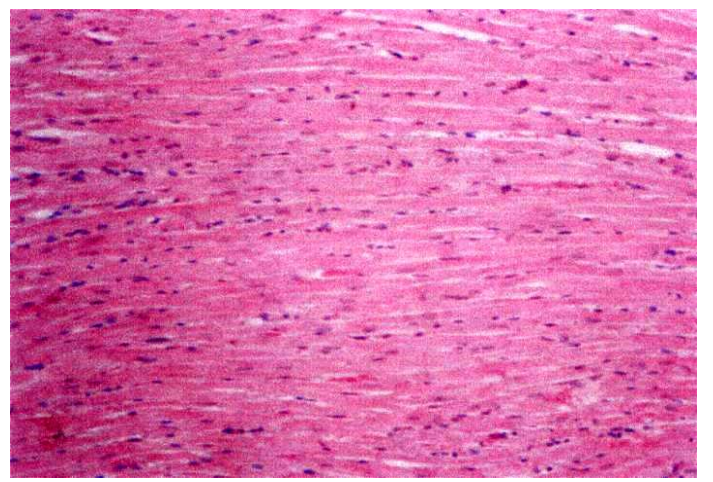

Fig. 1. Photomicrograph of heart for normal control (group No. 1).

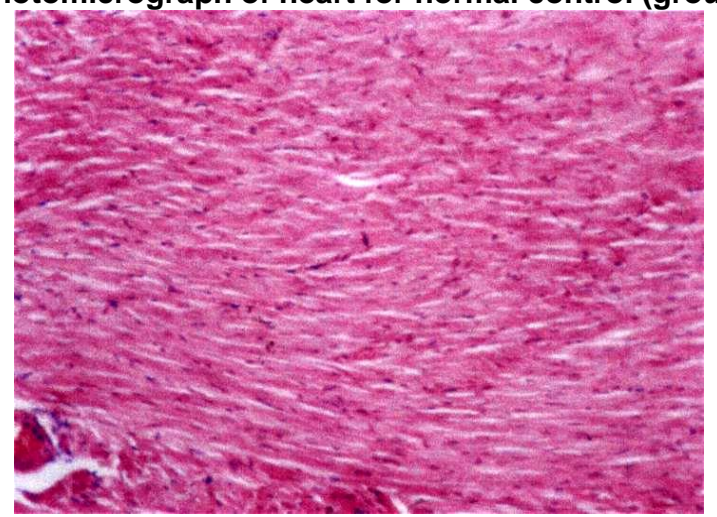

Fig. 2. Photomicrograph of heart for anemic control (group No. 2)

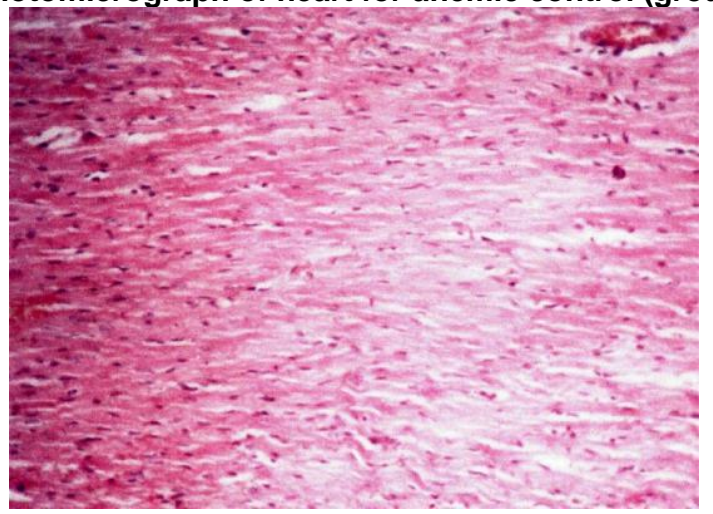

Fig. 3. Photomicrograph of heart for (group No. 5)

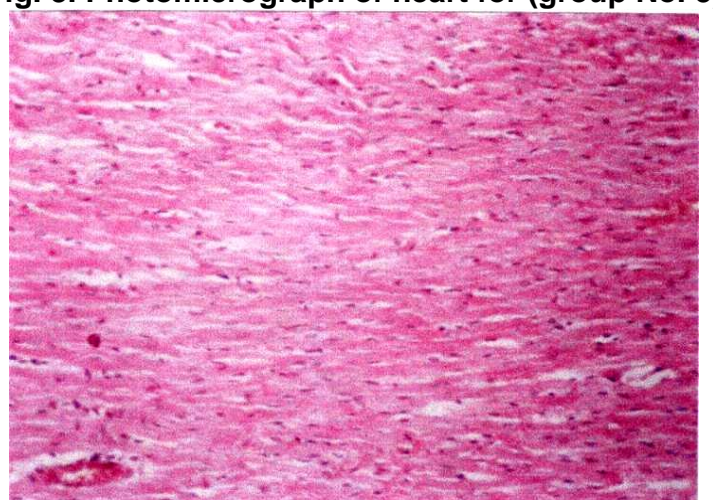

Fig. 4. Photomicrograph of heart for (group No. 8)

Arab Univ. J. Agric. Sci., 18(2), 2010 


\section{REFERENCES}

AACC (2002). Approved Methods of American Association of Cereal Chemists. Inc. St. Paul,. Minnesota, USA.

AIN (1977). American Institute of Nutrition: Report of the American Institute ad hoc Committee on Standards for Nutritional Studies. J. Nutr., 107: 1340-1348.

AOAC (2005). Official Methods of Analysis. $18^{\text {th }}$ Ed. Association of Official Analytical Chemists. Arlington, Virginia, USA.

Barbara, T.; I. Egli; C. Zeder; R. Hurrell and M. Zimmermann (2009). Optimization of a phytase containing micronutrient powder with low amounts of highly bioavailable iron for in home fortification of complementary foods. Am. J. Clin. Nutr., 89: 539-544.

Bassiouny, S.S.; F.A. Abd El-Razik and S.E. ElNemer (1990). Effect of addition of herbs on sensory quality of selected bakery products. Egypt. J. Food Sci., 18 (1): 121-136.

Dacie, J.V. and S.M. Lewis (1984). Practical Haematology. $6^{\text {th }}$ Ed., pp. 28-117. Churchill Livingston, London.

Ekhard, E.Z.; S.E. Nelson and J.M. Jeter (2009). Iron status of breastfed infants is improved equally by medicinal iron and iron fortified cereal. Am. J. Clin. Nutr., 90: 76-87.

Farrell, K.T. (1999). Spices Condiments and Seasonings. $2^{\text {nd }}$ Ed., pp. 91-94. The AVI Publishing Co., Inc., Westport, Connecticut.

Flowers, C.; M. Cuizon; J. Beard; B. Skinke and J. Cook (1986). Serum ferritin assay for the prevalence studies of iron deficiency. Am. J. Hematol., 23: 141-151.

Heplar, O.E. (1966). Manual of clinical laboratory methods. Thomas; Spring Field, Illinois, USA. Am. J. Clin. Nutr., 89: 525-532.

Janet, R.; C. Ann and L. Johnson (2009). Body iron excretion by healthy men and women. Am. J. Clin. Nutr., 89: 525-532.

John, B. and T. Brian (2002). Iron status and exercise. Am. J. Clin. Nutr., 71: 1147-1160.

Laura, E.M. and J.L. Beard (2009). Iron deficiency and child and maternal health. Am. J. Clin. Nutr., 89: 946-950.
Leif, H. and H. Lena (2000). Prediction of dietary iron absorption: an algorithm for calculating absorption and bioavailability of dietary iron. Am. J. Clin. Nutr., 71: 1147-1160.

Mark, R.; R. Collings; J. Dainty; D. Swinkels and S. Fairweather (2009). Hepcidin concentrations significantly predict interindividual variation in iron absorption in healthy men. Am. J. Clin. Nutr., 89: 1088-1091.

Melissa, F.; R. Glahn; J. Inglis; G. Oibina and M. Westerman (2009). Serum hepcidin is significantly associated with iron absorption from food and supplemental sources in healthy young women. Am. J. Clin. Nutr., 89: 533538.

Sandrine, P.; L. Douchet; A. Vergnaud; C. Estaquio and P. Galan (2008). Relationship between iron status and dietary fruit and vegetables based on their vitamin $\mathrm{C}$ and fiber content. Am. J. Clin. Nutr., 87: 1374-1383.

SAS (2001). Statistical Analysis System. SAS User's Guide: Statistics (Version 6.0). SAS Inst. Inc. Cary. NC. USA.

Schricker, B.R. and D.D. Miller (1982). In vitro estimation of relative iron availability in breads and meals containing different forms of fortification iron. J. Food Sci., 47: 723-727.

Shogren, M.D.; Y. Pomeranz and K.E. Finney (1981). Counteracting the deleterious effect of fiber in breadmaking. Cereal Chem., 58 (2): 142-144.

Wade, P. (1988). Biscuits, Cookies and Crackers. Recipe of Biscuits Used During Investigation 1: 102-114. Applied Science Publishers LTD, London, UK.

Wintrobe, M.M. (1965). Clinical Hematology. $4^{\text {th }}$ Ed., pp. 218-231. Leadn Febiger, Philadelphia, USA.

Yoon, B.I.; Y.K. Choi; D.Y. Kim; B.H. Hyun; K.H. Joo and H.J. Rimand (2001). Infectivity and pathological changes in murine clonorchiasis: comparison in immunocompetent and immunodeficient mice. J. Vet. Med. Sci., 63 (4): 421-425.

Zhenyu, Y.; K. Dewey; O. Hernell; C. Chaparro and K. Brown (2008). Comparison of plasma ferritin concentration with the ratio of plasma tranferrin receptor to ferritin in estimating body iron store: results of 4 intervention trials. Am. J. Clin. Nutr., 87: 1892-1898. 